\title{
ASUPAN ZAT GIZI DAN ANEMIA PADA REMAJA PUTRI DI SALAH SATU SLTP KOTA PEKANBARU
}

\author{
Yanti Ernalia, Lusiana Tamba \\ UIN Sultan Syarif Kasim Riau, Stikes Hangtuah Pekanbaru \\ yanti.ernalia@uin-suska.ac.id
}

\begin{abstract}
Anaemia is an important nutritional problems in Indonesia, including in Pekanbaru City in Riau Province. Nutrient consumption are related to anaemia in young women. The study aimed to determine the pevalence of anaemia in young women at one of the schools in Pekanbaru, as well as in relation to nutrient intake. The study design was cross-sectional by analityc obsevational. Subjects consisted of 57 adolescents with purposive sampling technique. Data of consumption was obtained from 24 hours food recall, and data of anaemia were obtained by hemocue with digital hemoglobinometry. Pearson chi-square test for independence (categorical variables) and test for independent sample t-test (continuous variables) were used for statistical data analysis. There were 11 subjects (19.3\%) who suffered from anemia. Most of adolescents had a deficiency in cobalamin, folic acid, fe, and protein consumption. Difference in average of cobalamin, folic acid, fe, and protein consumption was no significant between anaemia and non anaemia adolescents $(\mathrm{p}>0.05)$. Protein consumption was related to anaemia $(\mathrm{p}=0.041$ \&Prevalens Ratio $(\mathrm{PR})=5.83$ ). Detection of nutritional status (dietary behavior) is needed to protect the incidence of anaemia of adolescent girls, and increased nutrition intake of adolescents through information, communication, and nutrition education.
\end{abstract}

Keywords: anaemia, adolescents, consumption, nutrition,women

\begin{abstract}
Abstrak: Remaja putri yang mengalami anemia masih menjadi masalah gizi penting di Indonesia, termasuk Kota Pekanbaru Provinsi Riau Indonesia. Salah satu penyebab anemia remaja putri adalah asupan zat gizi. Tujuan penelitian adalah untuk menganalisis kejadian anemia pada remaja putri pada satu Sekolah Lanjutan Tingkat Pertama (SLTP) Kota Pekanbaru, serta kaitannya dengan asupan zat gizi. Penelitian ini merupakan penelitian observasional analitik dengan desain cross-sectional.Pemilihan subjek menggunakan teknik purposive sampling, dan diperoleh sebanyak 57 siswi. Metode wawancara foodrecall selama 24 jam menggunakan kuesioner dilakukan untuk memperoleh data konsumsi (asupan) zat gizi. Hasil hemoglobin remaja diperoleh dengan metode hemocue menggunakan hemoglobinometer digital. Data yang telah dikumpulkan, diolah menggunakan analisis statistik uji chi-square dan independent sample t-test. Diperoleh hasil 11 remaja putri $(19,3 \%)$ mengalami anemia. Sebagian besar subjek memiliki ketidakcukupan asupan kobalamin (vitamin B12), asam folat, fe (zat besi), dan protein. Terdapat perbedaan rerata kobalamin, asam folat, fe, dan protein antara remaja putri yang mengalami anemia dengan yang tidak, namun tidak bermakna secara statistik. Terdapat kaitan antara asupan zat gizi protein dengan dengan anemia ( $\mathrm{p}=0,041$ dan Risiko Prevalens $(\mathrm{RP})=5,83$ ) pada remaja putri di tingkat SLTP. Diperlukan pemantauan status gizi (riwayat gizi) remaja putri yang termasuk kategori golongan wanita usia subur dan peningkatan asupan gizi remaja melalui komunikasi informasi, dan edukasi gizi.
\end{abstract}

Kata Kunci : anemia, asupan, gizi, perempuan, remaja.

Anemia defisiensi gizi masih umum
dijumpai pada remaja putri (Pritasari et al.,


RI, 2014). Remaja wanita akan mengalami siklus menjadi dewasa dan menjadi calon ibu hamil. Ibu hamil di Indonesia yang mengalami anemia adalah $48,9 \%$ dan 84,6 $\%$ diantaranya terjadi pada fase remaja (Kemenkes RI, 2018). Anemia remaja putri lebih banyak di jumpai pada fase remaja awal (10-14 tahun) dibandingkan dengan remaja akhir (15-19 tahun) (Chandrakumari et al., 2019). Fase remaja awal ini berada pada sekitaran tingkat Sekolah Lanjutan Tingkat pertama. Berdasarkan salah satu penelitian pada remaja perempuan di salah satu SLTP Kota Pekanbaru diketahui prevalensi anemia sebesar 15,7\% (Angrainy etal., 2019).

Anemia dapat disebabkan oleh beberapa faktor. Berbagai penyakit dasar dapat menyebabkan anemia (Bakta, 2015). Menstruasi merupakan salah satu faktor kehilangan zat besi pada remaja (Arisman, 2014). Zat gizi pada asupan makanan remaja sangat penting. Terdapat kaitan antara asupan vitamin $\mathrm{C}$, fe, vitamin B12, dan protein terhadap anemia pada perempuan usia muda di Kota makasar (Syatriani \& Aryani, 2010). Tidak beragamnya asupan makanan dan pengetahuan yang kurang merupakan faktor risiko anemia pada remaja (Chalise et al., 2018 \& Gebreyesus et al., 2019). Anemia Defisiensi Besi juga dapat disebabkan oleh gangguan penyerapan zat gizi dan defisiensi gizi (Zariwala et al., 2013). Asupan makanan dan atau penyerapan zat gizi yang buruk dari zat besi, vitamin B12, vitamin B6, vitamin C, dan tembaga merupakan faktor pendorong terjadinya anemia gizi pada usia remaja. (Adriani, 2012).Berdasarkan National Family Health Survey (NFHS) kejadian malnutrisi pada remaja di India terkait masalah anemia terjadi pada golongan ekonomi rendah dan juga pada golongan ekonomi tinggi (Punjab, 2016)

Anemia pada remaja menyebabkan kerentanan terhadap infeksi, gangguan pertumbuhan dan perkembangan serta penurunan kebugaran fisik ( Jain et al., 2012). Strategi untuk mengurangi prevalensi anemia defisiensi besi pada remaja adalah dengan cara suplementasi besi, fortifikasi makanan,dan meningkatkan ketahanan pangan (Habib et al., 2018). Program suplementasi tablet $\mathrm{Fe}$ (zat besi) berhasil efektif menanggulangi kejadian anemia pada remaja putri (et al., 2019)

\section{BAHAN DAN CARA KERJA}

Penelitian ini merupakan penelitian observasional analitik dengan desain crosssectional. Penelitian dilakukan di salah satu SLTP Kota Pekanbaru dengan jumlah subjek sebanyak 57 siswa berusia 11-13 tahun dengan teknik purposive sampling. Metode wawancara menggunakan kuesioner foodrecall selama satu hari (24 jam) dilakukan untuk memperoleh data asupan gizi remaja putri. Data anemia remaja 
diperoleh dengan pengukuran hemoglobin menggunakan metode

Heтосие menggunakan hemoglobinometer digital. Ketepatan metode ini dan keakuratan alat dilaporkan memiliki sensitivitas alat $89,4 \%$ spesifisitas alat $63,6 \%$ untuk mengukur hemoglobin dibandingkan dengan analisis laboratorium (Toppo, 2019). Remaja putri dikatakan anemia bila kadar hemoglobin (Hb) dalam darah $<12 \mathrm{~g} / \mathrm{dl}$. Data yang telah dikumpulkan, dipaparkan secara univariat, dan juga dilakukan analisis secara bivariat. Pada saat pengukuran remaja putri tidak sedang dalam keadaan menstruasi.

\section{HASIL}

Gambaran umum latar belakang subjek remaja putri dipaparkan pada Tabel 1 .

Tabel 1. Karakteristik Remaja Putri

\begin{tabular}{lll}
\hline Variabel & N (Jumlah) & $\begin{array}{l}\% \\
\text { (Persen) }\end{array}$ \\
\hline Umur $\quad 10-12$ tahun & 15 & 26.3 \\
a. $\quad 42-15$ tahun & 42 & 73.7 \\
b. $\quad 11$ & 19.3 \\
$\begin{array}{l}\text { Status Anemia : } \\
\text { a. Anemia } \\
\text { b. Tidak Anemia }\end{array}$ & 46 & 80.7 \\
$\begin{array}{l}\text { Asupan Kobalamin } \\
\text { a. Kurang (<80\% ) }\end{array}$ & 32 & 56.1 \\
b. Cukup ( $\geq 80 \%$ AKG) & 25 & 43.9 \\
$\begin{array}{l}\text { Asupan Asam Folat } \\
\text { a. Kurang (<80\% AKG) }\end{array}$ & 57 & 100 \\
b. Cukup ( $\geq 80 \%$ AKG) & 0 & 0 \\
$\begin{array}{l}\text { Asupan Protein } \\
\text { a. Kurang (<80\% AKG) } \\
\text { b.Cukup ( } \geq 80 \% \text { AKG) }\end{array}$ & 36 & 63.2 \\
Asupan Zat Besi (Fe) & 21 & 36.8 \\
$\begin{array}{l}\text { a. Kurang (<80\% AKG) } \\
\text { b. Cukup ( } \geq 80 \% \text { AKG) }\end{array}$ & 57 & 100 \\
& 0 & 0 \\
\hline
\end{tabular}

Berdasarkan Tabel 1 diatas diketahui $19.3 \%$ remaja putri mengalami anemia. Secara keseluruhan asupan kobalamin, asam folat, fe, dan protein pada remaja masih kurang. Kategori asupan asam folat dan zat besi pada remaja putri keselurahannya < 80\% AKG (Angka Kecukupan Gizi)

Tabel 2. Kaitan antara Karakteristik Usia dan Asupan Gizi dengan Anemia Remaja Putri

\begin{tabular}{|c|c|c|c|c|c|c|}
\hline \multirow[t]{2}{*}{ Variabel } & \multicolumn{2}{|c|}{ Anemia (11) } & \multicolumn{2}{|c|}{$\begin{array}{c}\text { Tidak } \\
\text { Anemia } \\
(46)\end{array}$} & \multirow[t]{2}{*}{$\begin{array}{c}\text { P } \\
\text { Val } \\
\text { ue } \\
\end{array}$} & \multirow[t]{2}{*}{$\mathrm{RP}$} \\
\hline & $\mathrm{N}$ & $\%$ & $\mathrm{~N}$ & $\%$ & & \\
\hline Umur & & & & & $\begin{array}{r}0.7 \\
09\end{array}$ & 0.622 \\
\hline a. $\begin{array}{ll}10-12 \\
\text { tahun }\end{array}$ & 2 & $\begin{array}{c}13 . \\
3\end{array}$ & 13 & $\begin{array}{c}86 . \\
7\end{array}$ & & \\
\hline $\begin{array}{l}\text { b. } \begin{array}{l}13-15 \\
\text { tahun }\end{array}\end{array}$ & 9 & $\begin{array}{c}21 . \\
4\end{array}$ & 33 & $\begin{array}{c}78 . \\
6\end{array}$ & & \\
\hline $\begin{array}{l}\text { Aupan } \\
\quad \text { Protein }\end{array}$ & & & & & $\begin{array}{l}0,0 \\
41\end{array}$ & 5.83 \\
\hline a. $\begin{array}{l}\text { Kurang } \\
(<80 \%\end{array}$ & 10 & $\begin{array}{c}27 . \\
8\end{array}$ & 26 & $\begin{array}{c}72 . \\
2\end{array}$ & & \\
\hline 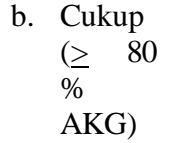 & 1 & 4.8 & 20 & $\begin{array}{c}95 . \\
2\end{array}$ & & \\
\hline $\begin{array}{l}\text { Asupan } \\
\text { Kobala } \\
\text { min }\end{array}$ & & & & & & \\
\hline $\begin{array}{ll}\text { a. } & \text { Kurang } \\
& (<80 \% \\
& \text { AKG })\end{array}$ & 7 & $\begin{array}{c}21 . \\
9\end{array}$ & 25 & $\begin{array}{c}78 . \\
1\end{array}$ & $\begin{array}{l}0.7 \\
39\end{array}$ & 1.367 \\
\hline $\begin{array}{ll}\text { b. } & \text { Cukup } \\
(\geq \quad 80 \\
\% \\
\text { AKG }) \\
\end{array}$ & 4 & 16 & 21 & 84 & & \\
\hline
\end{tabular}

Berdasarkan Tabel 2 diketahui protein merupan satu satunya intake (asupan) zat gizi remaja putri yang memiliki keterkaitan dengan anemia dengan Risiko Prevalens $(\mathrm{RP})=5,83$ dan $p$ value $=0,041$

Rerata asupan kobalamin, asam folat, fe, dan protein secara berurutan dalam penelitian ini yaitu: $2,8 \mathrm{mg}, 76,3 \mu \mathrm{g}, 5,9 \mathrm{mg}$, dan 52,7 g. Perbedaan Asupan zat gizi berdasarkan status anemia pada remaja putri dapat diketahui dari Tabel 3. 
Tabel 3. Perbedaan Asupan Zat Gizi Berdasarkan Status Anemia pada Remaja Putri

\begin{tabular}{|c|c|c|c|c|}
\hline $\begin{array}{l}\text { Asupan Zat } \\
\text { Gizi }\end{array}$ & $\begin{array}{c}\text { Anemi } \\
\mathrm{a} \\
(\mathrm{N}=11) \\
\mathrm{X} \pm \\
\mathrm{SD}\end{array}$ & $\begin{array}{c}\text { Tidak } \\
\text { Anemia } \\
(\mathrm{N}=46) \\
\mathrm{X} \pm \mathrm{SD}\end{array}$ & $\begin{array}{c}\text { Mean } \\
\text { Differe } \\
\text { nce }\end{array}$ & $\mathrm{P}$ \\
\hline Asupan & $2.28 \pm$ & $2.95 \pm$ & 0.67 & 0.18 \\
\hline $\begin{array}{l}\text { Kobalamin } \\
(\mathrm{mg})\end{array}$ & 1.29 & 3.00 & & \\
\hline Asupan & $79.65 \pm$ & $75.50 \pm$ & 4.15 & 0.11 \\
\hline $\begin{array}{l}\text { asam folat } \\
(\mu \mathrm{g})\end{array}$ & 29.69 & 54.06 & & \\
\hline Asupan zat & $5.30 \pm$ & $6.05 \pm 6.83$ & 0.75 & 0.65 \\
\hline besi (mg) & 3.05 & & & \\
\hline Asupan & 43.68 & $54.87 \pm 23$ & 11.19 & 0.143 \\
\hline Protein $(\mathrm{g})$ & $\begin{array}{l} \pm \\
16.12\end{array}$ & 05 & & \\
\hline
\end{tabular}

Berdasarkan tabel di atas di ketahui bahwa rata-rata asupan kobalamin, fe, dan protein dalam satu hari lebih rendah pada remaja putri yang anemia, namun tidak ada perbedaan yang bermakna secara statistik. Rata-rata asupan asam folat dalam satu hari sedikit lebih tinggi pada remaja putri yang anemia, namun juga tidak terdapat perbedaan yang bermakna secara statistik

\section{PEMBAHASAN}

Prevalensi anemia remaja putri pada penelitian di salah satu SLTP di Kota Pekanbaru Provinsi Riau adalah 19.3\%. Angka ini lebih rendah dibandingkan dengan angka $26,5 \%$ remaja putridi Indonesia mengalami anemia (Kemenkes RI, 2014). Selain itu juga jauh lebih rendah dibandingkan penelitian terdahulu sebanyak $43 \%$ remaja putri mengalami anemia di kota Bengkulu (Suryani etal 2015). Penelitian pada 749 anak usia 5 - 10 tahun di Srilanka prevalensi anemia sebesar 17,3\% (Naotunna et al., 2017). Berdasarkan kriteria WHO prevalensi anemia 5 - 19,9\% termasuk permasalahan kesehatan ringan (WHO, 2010).

Rerata asupan asam folat dan juga fe (zat besi) secara keseluruhan pada remaja putri kurang dari $80 \%$ AKG. AKG zat besi pada remaja (10-12 \&13-15) tahun, secara berurutan adalah $20 \mathrm{mg}$ dan $26 \mathrm{mg}$ (Kemenkes RI, 2014). Asupan zat besi yang kurang ini menyebabkan remaja putri rentan mengalami anemia. Zat besi merupakan mikronutrient esensial bagi tubuh dalam sintesa hemoglobin ( Susianto \& Ramayulis, 2013). Hasil telaah kuesioner food recall diketahui bahwa remaja putri sering melewatkan sarapan pagi, mengkonsumsi makanan jajanan yang tinggi lemak, dan karbohidrat,namun kurang akan asupan kobalamin, asam folat, fe, dan protein. Zat besi pada makanan dibagi dua heme dan non heme. Sumber makanan zat besi heme yaitu telur, ikan, dan daging, miglobin dalam makanan tersebut menyediakan besi heme yang diabsorpsi dengan baik. Sumber makanan zat besi non heme yaitu dari biji bijian, kacang-kacangan, sayur, tofu, dan juga produk susu (Gropper \& Smith, 2013). Terdapat $19.7 \%$ wanita yang tidak sedang dalam keadaan hamil di wilayah Azerbaijani mengalami defisiensi kobalamin, $35 \%$ 
defisiensi asam folat, dan $23,85 \%$ anemia gizi besi (Wirth et al., 2018)

Hasil penelitian ini menyebutkan bahwa 32 siswi (56.1\%) memiliki asupan kobalamin kurang dari 80\% AKG (Tabel 1). AKG Kobalamin berdasarkan Peraturan menteri Kesehatan pada remaja (10-12\&1315) tahun secara berurutan adalah adalah 1,6 mg dan 2,4 mg (Kemenkes RI, 2014). Hasil ini berbeda dari riset sebelumnya pada remaja putri di SLTP 9 Jawa tengah (Semarang), di sana rata-rata asupan kobalamin dan asam folat tercukupi dari telur, susu, sayur bayam, hati, buah, kacang (Indartanti et al., 2014). Remaja putri pada penelitian ini kekurangan asupan kobalamin yang bersumber dari ganggang dan rumput laut (bagi vegetarian), juga ikan, kati, daging, susu, , dan telur (Gropper \& Smith, 2013). Prevalensi defisiensi Kobalamin (Vitamin B12) lebih jarang ditemukan di kelompok perempuan dibandingkan laki-laki (19,9\%: 25,5\%), dan laki-laki 2,6 x lebih berisiko menderita defisiensi vitamin B 12 dibandingkan perempuan (Margalit et al., 2018)

Kategori usia dengan anemia tidak berkaitan pada penelitian ini. Penelitian ini terdiri dari remaja putri yang berusia 10-12 tahun $(26,3 \%)$ dan usia $12-14$ tahun $(73,7$ $\%)$. Hasil ini berbeda dengan data yang diperoleh pada remaja China dikethui bahwa anemia banyak terjadi pada usia 6-8 tahun, 12-14 tahun, dan 15-17 tahun (Jinghuan et al., 2019). Berdasarkan Tabel 2 diketahui protein merupan satu satunya intake (asupan) zat gizi remaja putri yang memiliki keterkaitan dengan anemia. Remaja putri dengan kategori asupan protein kurang dari $80 \%$ AKG berpeluang 6x (enam kali) lebih berisiko menderita anemia daripada yang memiliki asupan dengan kategori cukup. Asupan protein yang memadai berguna untuk menjaga kadar hemoglobin darah dalam tubuh sehingga dapat mencegah timbulnya anemia (Kirana \& Kartini, 2011) Protein (metalloproteins) memiliki fungsi untuk menyimpan mineral pada organ tubuh (termasuk fe/zat besi) (Gropper \& Smith, 2013). Remaja putri yang mengalami anemia memiliki kebiasaan makan yang lebih kurang sehat dibandingkan remaja putri yang normal, lebih sering memilih makanan selingan tidak bergizi, dan kurang konsumsi sumber buah yang mengandung vitamin $\mathrm{C}$ dalam jumlah tinggi, serta jarang mengkonsumsi makanan hewani (Akib \& Sumarni, 2017). Protein di butuhkan untuk pembentukan ikatan esensial tubuh yaitu hemoglobin (Susianto \& Ramayulis, 2013). Hemoglobin merupakan bagian dari sel darah merah yang terdiri dari ikatan garam besi, protein, dan zat warna (Adriani, 2012)

Konsumsi/asupan kobalamin pada subjek penelitian tidak memiliki hubungan dengan anemia (Tabel 2). Hasil ini berbeda dengan penelitian di Kota Makasar pada 148 subjek (Mariana et al., 2015). Penelitian di 
siswi SLTP Kota diketahui sebagian besar remaja putri juga mengalami kekurangan vitamin B12 (kobalamin), asam folat, dan zat besi dan memiliki hubungan yang bermakna secara statistik dengan anemia (Saptayasih et al., 2016). Pada penelitian ini asupan kobalamin (vitamin B12) tidak berhubungan dimungkinkan karena tidak terdapat perbadaan proporsi yang signifikan yaitu yang asupan kobalaminnya kurang $(21,9 \%)$ menderita anemia, sedangkan yang asupannya cukup (16\%) mengalami anemia. Selain asupan kobalamin (vitamin B12) ada juga faktor lain yang memiliki kaitan dengan anemia. Faktor utama anemia pada negara berkembang adalah defisiensi gizi, inflamasi/infeksi, dan gangguan genetik hemoglobin (Chaparro \& Suchdev, 2019). Kobalamin bersama sama dengan asam folat berfungsi untuk sintesis dan metilasi asam nukleat (pembentukan sel darah merah) dan DNA (Mahajan et al., 2019).

Keseluruhan remaja putri memiliki asupan zat besi dan asam folat $<80$ persen AKG sehingga tidak dapat dianalisis lebih lanjut dengan uji statistik. Remaja putri pada penelitian ini kurang mengkonsumsi makanan sumber zat besi, kebiasaan remaja putri mengkonsumsi makanan hewani hanya satu kali sehari, dan sedikit yang biasa mengkonsumsi susu setiap hari. Berdasarkan hasil wawancara pada penelitian ini remaja dapat menyebutkan bahan makanan untuk mencegah anemia. Hal ini serupa dengan hasil penelitian kualitatif di Kota Peru yaitu pada remaja di kota peru sebagian besar dapat menyebutkan sumber makanan untuk pencegahan anemia seperti kacang-kacangan, sebagian besar remaja mendapatkan informasi dari internet, ada faktor dukungan ibu dalam menyiapkan makanan di rumah, dan ketersediaan makanan di sekolah juga mempengaruhi kejadian anemia pada remaja (Banna et al., 2016). Kurangnya konsumsi sayuran dan buah pada remaja perempuan di penelitian ini ini hampir sama dengan temuan bahwa 90 persen remaja putri di Asia Tenggara kurang konsumsi buah dan sayur (Keats et al., 2017). Rendahnya asupan energi dan zat gizi mikro merupakan masalah kesehatan terutama gizi bagi remaja (Ochola \& Masibo, 2014)

Konsumsi zat gizi kobalamin, fe, dan protein tidak ada perbedaan yang bermakna secara statistik, walaupun lebih rendah pada subjek yang mengalami anemia. Hal ini kemungkinan bisa terjadi karena selisih ratarata asupan kobalamin perhari antara remaja putri yang anemia dan yang tidak anemia adalah 0,67 mg dan sama sama sudah mencukupi ( $\geq 80 \% \quad \mathrm{AKG}) . \quad$ Walaupun terdapat perbedaan selisih rata-rata asupan protein yang cukup jauh sebanyak 11,19 g antara remaja putri yang anemia $(43,68 \mathrm{~g} /<$ $80 \%$ AKG) sedangkan remaja putri yang tidak anemia $(54,87 \mathrm{~g} / \geq 80 \% \mathrm{AKG})$ namun perbedaan ini tidak bermakna secara statitik. AKG protein berdasarkan Peraturan menteri 
Kesehatan pada remaja (10-12\&13-15) tahun secara berurutan adalah adalah $60 \mathrm{~g}$ dan 69 (Kemenkes RI, 2014). Untuk rata- rata asupan asupan zat besi antara remaja putri yang anemia dengan remaja putri yang tidak anemia sama sama masih kurang dari $(\leq 80 \%$ AKG) dengan selisih rata-rata $0,75 \mathrm{mg}$, namun perbedaan ini tidak bermakna secara statistik. Hal ini serupa dengan penelitian pada 1385 remaja putri di Kota Polish, yaitu tidak ada perbedaan asupan zat besi yang bermakna secara statistik (Skolmowska \& Głąbska, 2019). Rata-rata konsumsi / asupan zat besi remaja dalam satu hari pada penelitian ini sebesar 5,9 $\mathrm{mg}$, berbeda dengan remaja putri di Kota Polish rata-rata per hari sebesar 12,99 mg (Skolmowska \& Głąbska, 2019)

Rata-rata asupan asam folat dalam satu hari pada remaja yang mengalami anemia $(79,65 \mathrm{mg})$ lebih tinggi $4,15 \mu \mathrm{g} / \mathrm{hari}$ di bandingkan remaja putri yang tidak mengalami anemia $(75,50 \mathrm{mg})$, namun perbedaan ini sangat kecil dan tidak bermakna secara statistik. Hal ini dapat disebabkan pada penelitian ini rata-rata asupan asam folat remaja putri adalah 76.3 $\mu \mathrm{g}$, angka ini sangat rendah dibandingkan AKG asam folat untuk perempuan usia 10$12(190 \mu \mathrm{g})$ dan usia $13-15$ tahun $(240 \mu \mathrm{g})$. Seluruh remaja putri pada penelitian ini mengalami kekurangan asupan asam folat, terlihat berdasarkan hasil wawancara remaja putri jarang mengkonsumsi makanan yang kaya akan asam folat seperti sayuran berdaun hijau, jamur, kacang-kacangan, biji-bijian, pisang, strawberi, dan jeruk (Gropper \& Smith, 2013) dan hal ini sejalan dengan penelitian terdahulu $(\mathrm{p}=0,680)$ (Marina etal., 2015).Pada remaja putri usia produktif di Ethiopia, Kenya, Nigeria dan Afrika Selatan prevalensi defisiensi asam folat yaitu sekitar $46 \%$, dan asupan folat yang kurang merupakan faktor risiko terjadinya anemia (Harika et al., 2017). Besi dan asam folat dapat meningkatkan metabolisme tubuh, hal yang sama juga antara besi dan Vitamin B12. Peranan asam folat dalam proses sintesis nukleo protein merupakan kunci pembentukan dan produksi butir-butir darah merah normal. Kerja asam folat banyak berhubungan dengan kerja dari vitamin B12 (Kobalamin) (Sudargo, 2018)

\section{KESIMPULAN}

Kejadian anemia remaja putri di salah SLTP Kota Pekanbaru yaitu 19,3\%. Keseluruhan remaja putri kekurangan asupan zat besi dan asam folat, dan hampir sebagian besar juga mengalami kekurangan asupan protein dan kobalamin (vitamin B12). Terdapat perbedaan rerata kobalamin, asam folat, fe, dan protein antara remaja putri yang mengalami anemia dengan yang tidak, namun tidak bermakna secara statistik. Terdapat kaitan antara asupan zat gizi protein dengan dengan anemia $(\mathrm{p}=0.041$ dan $\mathrm{RP}=$ 
$5,83)$ pada remaja putri di tingkat SLTP Kota

Pekanbaru.

Asupan protein berkaitan dengan anemia (pada remaja putri) di salah satu SLTP Kota Pekanbaru. Diperlukan

\section{DAFTAR RUJUKAN}

Adriani, M. 2012. Pengantar Gizi Masyarakat. Jakarta : Prenada Media Grup

Akib, A., and Sumarni, S. (2017). Food Consumption Habits of Female Adolescents Related to Anemia: A Positive Deviance Approach. 105116.

https://doi.org/10.20473/amnt.v1.i2.2017.105116.

Angrainy, R., Fitri, L., \& Wulandari, V. (2019). Pengetahuan Remaja Putri Tentang Konsumsi Tablet Fe pada Saat Menstruasi dengan Anemia. Jurnal endurance : Kajian Ilmiah Problema Kesehatan vol 4 (2) Juni 2019 349).http://doi.org/10.22216/jen.v4i2.4100

Arisman, MB. (2014). Gizi Dalam Daur Kehidupan. Jakarta: EGC

Bakta, IM. (2015). Hematologi Klinik Ringkas. Jakarta: EGC

Banna, J. C., Buchthal, O. V., Delormier, T., CreedKanashiro, H. M.,\&Penny, M. E. (2016). Influences on eating: A qualitative study of adolescents in a periurban area in Lima, Peru.BMC Public Health, 16(1), 1-12. https://doi.org/10.1186/s12889-016-2724-7.

Chalise, B., Aryal, K. K., Mehta, R. K., Dhimal, M., Sapkota, F., Mehata, S.,Sawyer, S. (2018). Prevalence and correlates of anemia among adolescents in Nepal: Findings from a nationally representative cross-sectional survey. PLoS ONE, 13(12), 1-12. https://doi.org/10.1371/journal.pone.0208878

Chandrakumari, AS., Sinha, P., Singaravelu, S., Jaikumar, S. (2019). Prevalence of anaemia among adolescents girls in a rural are a of Tamil Nadu India. j Fam Med Prim Care. 2019; $8: 1414$

Chaparro, C. M \& Suchdev, P. S. (2019). Anemia epidemiology, pathophysiology, and etiology in low- and middle-income countries. Ann N Y Acad Sci Ann N Y Acad Sci . August 16. . 2019 August $\quad$; 1450(1): 15-31. https://doi.org/10.1111/nyas.14092.Anemia

Gebreyesus, S. H., Endris, B. S., Beyene, G. T., Farah, A. M., Elias, F., \& Bekele, H. N. (2019). Anaemia among adolescent girls in three districts in Ethiopia. BMC Public Health, 19(1), 1-12. https://doi.org/10.1186/s12889-019-64220 pemantauan status gizi (riwayat gizi) remaja putri yang termasuk kategori golongan wanita usia subur dan peningkatan asupan gizi remaja melalui komunikasi informasi, dan edukasi gizi.

Gropper, SS \& Smith, JL. (2013). Advanced Nutrition and Human Metabolism. Sixth Edition.USA:Wadsworth.

Habib, M. A., Raynes-Greenow, C., Soofi, S. B., Ali, N., Nausheen, S., Ahmed, I., Black, K. I. (2018). Prevalence and determinants of iron deficiency anemia among non-pregnant women of reproductive age in Pakistan. Asia Pacific

Journal of Clinical Nutrition, 27(1), 195-203. https://doi.org/10.6133/apjen.042017.14

Harika, R., Faber, M., Samuel, F., Kimiywe, J., Mulugeta, A., \& Eilander, A. (2017). Micronutrient status and dietary intake of iron, Vitamin A, iodine, folate and zinc in women of reproductive age and pregnant women in Ethiopia, Kenya, Nigeria and South Africa: A systematic review of data from 2005 to 2015. Nutrients, $9(10)$. https://doi.org/10.3390/nu9101096

Indartanti, Dea., Kartini, A. (2014). Hubungan Status Gizi Dengan Kejadian Anemia Pada Remaja Putri. Journal of Nutrition College, Volume 3, Nomor 2, Halaman 33-39. http://ejournals1.undip.ac.id/index.php/jnc. https://doi.org/10.14710/JNC.V3I2.5438.

Jain., M and Chandra., S. (2012). Correlation between haematological and cognitive profile of anaemic and non-anaemic school age girls CurrPediatr Res. 16 (2): 145-149.

Jinghuan, J., Hu, Y., Li, M., Chen, J., Mao, D., Li, W., Xiaoguang, X. (2019). Prevalence of anemia in chinese children and adolescents and its associated factors. International Journal of Environmental Research and Public Health, 16(8), $1-14$. https://doi.org/10.3390/ijerph16081416.

Kemenkes RI. (2014). Hasil Utama Rikesdas 2013. Jakarta : Badan Penelitian dan Pengembangan Kesehatan Republik Indonesia : Jakarta

Kemenkes RI. (2018). Hasil Utama Rikesdas 2018. Jakarta : Badan Penelitian dan Pengembangan Kesehatan Republik Indonesia : Jakarta

Kemenkes RI. (2014). Peraturan menteri Kesehatan (PMK) No 75. Jakarta : Kementerian Kesehatan RI.

Keats, EC.,Rappapor, A., Jain, R., Shah, S., \& Bhuta, ZA. (2017). Diet and eating practices among adolescent girls in low and middle income countries: A systematic review. Annals of 
Nutrition and Metabolism, 71(Supplement 2), 690.

https://doi.org/http://dx.doi.org/10.1159/000480 486.

Kirana, D.P., Kartni, A. (2011). Hubungan asupan zat gizi dan pola menstruasi dengan kejadian anemia pada remaja putri di SMA $\mathrm{N} 2$ Semarang. http://eprints.undip.ac.id/32594.

Mahajan, A., Sapehia D., Thakur S., Mohanraj PS, Bagga R., Kaur J. (2019). Effect of imbalance in folateand vitamin B12 in maternal/ parental diet on global methylation and regulatory miRNAs. Scientific 9:17602https://doi.org/10.1038/s41598-01954070-9

Margalit, I., Cohen, E., Goldberg, E., \& Krause, I. (2018). Vitamin B12 Deficiency and the Role of Gender: A Cross-Sectional Study of a Large Cohort. Annals of Nutrition and Metabolism, 72(4), 265-271. https://doi.org/10.1159/000488326.

Marina, Indriasari, R., \& Jafar, N. (2015). Konsumsi Tanin dan Fitat Sebagai Determinan Penyebab Anemia pada Remaja Putri di SMA Negeri 10 Makassar. Jurnal MKMI, 6, 54-57.

Naotunna, N. P. G. C. R., Dayarathna, M., Maheshi, H., Amarasinghe, G. S., Kithmini, V. S., Rathnayaka, M.,Agampodi, S. B. (2017). Nutritional status among primary school children in rural Sri Lanka; A public health challenge for a country with high child health standards.BMC Public Health, 17(1), 1-12. https://doi.org/10.1186/s12889-016-4001-1

Nuraeni, R., Sari, P., Martini, N., Astuti, S., Rahmiati, L. (2019) Peningkatan kadar hemoglobin melalui pemeriksaan dan pemberian tablet $\mathrm{Fe}$ terhadap remaja yang mengalami anemia melalui "Gerakan Jumat Pintar". Jurnal Pengabdian kepada Mayarakat UGM. Vol.5 (2), 200-221. http://doi.org/10.22146/jkpm.40570.

Ochola, S., \& Masibo, P. K. iny. (2014). Dietary intake of schoolchildren and adolescents in developing countries. Annals of Nutrition \& Metabolism, 64, 24-40. https://doi.org/10.1159/000365125

Punjab, W. (2016). Reminiscences from Indian Pediatrics: A Tale of 50 Years Growth, Nutritional status and Anemia in Indian Adolescents. 18-20.

Pritasari, Damayanti, D \& Lestari, NT. (2017). Bahan Ajar Gizi : Gizi Dalam Daur Kehidupan.Kemenkes : Jakarta.

Saptayasih, ARN., Widajanti,L., \& Nugraheni, SA.
(2016). Hubungan asupan zat besi, asam folat, vitamin b12 dan vitamin c dengan kadar hemoglobin siswa di smp negeri 2 tawangharjo kabupaten groboganJurnal Kesehatan Masyarakat Volume 4, Nomor 4, Oktober 2016 (ISSN: 2356-3346).http://ejournals1.undip.ac.id/index.php/jkm

Skolmowska, D., \& Głąbska, D. (2019). Analysis of heme and non-heme iron intake and iron dietary sources in adolescent menstruating females in a national Polish sample. Nutrients, 11(5). https://doi.org/10.3390/nu11051049

Syatriani, S., \& Aryani, A. (2010). Konsumsi Makanan dan Kejadian Anemia pada Siswi Salah Satu SMP di Kota Makassar. Kesmas: National Public Health Journal, 4(6), 251. https://doi.org/10.21109/kesmas.v4i6.163

Sudargo, T., Kusmayanti, NA., Hidayati, NL. (2018). Yogyakarta : Gadjah Mada University Press

Suryani, D., Hafiani, R., Junita, R. (2015).analisis pola makan dan anemia gizi besi pada remaja putri kota Bengkulu.Jurnal Kesehatan Masyarakat Andalas, Oktober 2015 - Maret 2016, Vol. 10, No. 1, Hal. 11-18.

Susianto \& Ramayulis, R. (2013). Fakta Ajaib Khasiat Tempe. Jakarta : Penerbar Plus

Toppo M, Pal DK, Gour D, Melwani V, Dubey M, Mishra A. (2019). Comparison of Performance of Digital Hemoglobinometer over Automated Hematology. Analyzer for Hemoglobin Estimation and Its user-friendliness among the Pregnant Women in Selected District Hospitals of Madhya Pradesh. Indian J Community Med. Jan-Mar 2019;44(1):31-34. doi: 10.4103/ijcm. IJCM_216_18

Wirth, J. P., Rajabov, T., Petry, N., Woodruff, B. A., Shafique, N. B., Mustafa, R., Rohner, F. (2018). Micronutrient deficiencies, over-and undernutrition, and their contribution to anemia in azerbaijani preschool children and nonpregnant women of reproductive age. Nutrients, 10(10). https://doi.org/10.3390/nu10101483

WHO. (2010). Nutrition Landscape Information System (NLIS) : Country Profile Indicators, Interpretation Guide. (Online).

Http://www.who.int/nutrition/nlis_interpretation guide_isbn9789241599955/en/

Zariwala MG, Somavarapu S, Farnaud S, et al. (2013). Comparison study of oral iron preparations usin a human intestinal model. Sci Pharm 81: 1123-1139. 21;81(4):1123-39. doi: 10.3797/scipharm.1304-03 